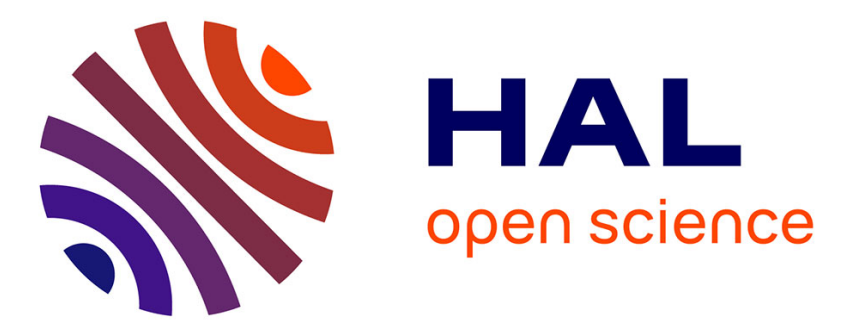

\title{
Modelling impact of northerly wind-generated waves on sediments resuspensions in the Dover Strait and adjacent waters
}

Nicolas Guillou, Georges Chapalain

\section{- To cite this version:}

Nicolas Guillou, Georges Chapalain. Modelling impact of northerly wind-generated waves on sediments resuspensions in the Dover Strait and adjacent waters. Continental Shelf Research, 2011, 31 (18), pp.1894-1903. 10.1016/j.csr.2011.08.011 . hal-01673392

\section{HAL Id: hal-01673392 \\ https://hal.science/hal-01673392}

Submitted on 15 Mar 2019

HAL is a multi-disciplinary open access archive for the deposit and dissemination of scientific research documents, whether they are published or not. The documents may come from teaching and research institutions in France or abroad, or from public or private research centers.
L'archive ouverte pluridisciplinaire HAL, est destinée au dépôt et à la diffusion de documents scientifiques de niveau recherche, publiés ou non, émanant des établissements d'enseignement et de recherche français ou étrangers, des laboratoires publics ou privés. 


\title{
Modelling impact of northerly wind-generated waves on sediments resuspensions in the Dover Strait and adjacent waters
}

\author{
Nicolas Guillou $^{\mathrm{a}, *}$, Georges Chapalain ${ }^{\mathrm{a}}$ \\ ${ }^{a}$ Laboratoire de Génie Côtier et Environnement, Centre d'Etudes Techniques Maritimes et Fluviales, \\ 155 rue Pierre Bouguer, Technopôle Brest-Iroise, BP 5, 29280 Plouzané, France.
}

\begin{abstract}
The present study investigates the effect of a storm on the resuspensions of heterogeneous sediments in the eastern English Channel. The numerical approach is based on the coupling of the wave propagation module SWAN (Simulating WAves Nearshore) with the three-dimensional circulation module COHERENS (COupled HydrodynamicalEcological model for RegioNal and Shelf seas). Suspended sediment transport is computed for the four grain-size classes of silts $\left(d_{1}=25 \mu \mathrm{m}\right)$, very fine sands $\left(d_{2}=75 \mu \mathrm{m}\right)$, fine sands $\left(d_{3}=150 \mu \mathrm{m}\right)$ and medium sands $\left(d_{4}=350 \mu \mathrm{m}\right)$. The application focuses on a storm in October 1998. Predicted times histories of waves variables and the nearbottom mean current and total suspended sediment concentration (SSC) are compared with field data collected off Merlimont Beach, in the south of Boulogne-sur-Mer. Mappings of the increases of the near-bottom total SSC during the storm are produced. The total SSC increases by four at the Merlimont site. The multiplying factor reaches 40 along the exposed northern French coastline revealing the Flandres bed features. This increase is limited to five in deep waters of the southern Dover Strait with local strengthening on the top of the Vergoyer and the Bassure de Baas sandbanks. The storm modifies the granulometric composition of suspended materials by increasing the contribution of medium sands. Main modifications appear at the south-western entrance of the Dover Strait and in the exposed southern North Sea. The near-bottom resuspensions remain elsewhere dominated by the local resuspensions of fine sands added to remote resuspended silts advected by currents.
\end{abstract}

Keywords: modelling, wave, tidal current, suspension, heterogeneous sediments, eastern English Channel, Dover Strait, southern North Sea

\footnotetext{
* Corresponding author

Email addresses: nicolas.guillou@developpement-durable.gouv.fr (Nicolas Guillou ), georges. chapalain@developpement-durable.gouv.fr (Georges Chapalain)

Preprint submitted to Continental Shelf Research

February 1, 2011
} 


\section{Introduction}

The Dover Strait connecting the eastern English Channel with the southern North Sea is a shallow environment (Fig. 1) with strong tidal currents reaching $2 \mathrm{~m} \mathrm{~s}^{-1}$ and quite heterogeneous bottom sediments including gravels, sands and silts. In addition to scarce field observations (e.g., Beck et al., 1991), numerical modelling have largely contributed to a better knowledge of tide-induced sediment transport in this area. The early approaches combined outputs of bi-dimensional horizontal (2DH) hydrodynamic models with empirical formulae for computing bedload transport rates (e.g., Grochowski et al., 1993a,b). Suspended sediment load was determined in a quasi-three-dimensional (3D) way which ignores horizontal advection and dispersion by currents. Some attempts to compute suspended sediment transport with fully 3D models came later (e.g., Souza et al., 2007). The sediment was always assumed to be made of a single class of particles. The exception was provided by Guillou et al. (2009) who considered the representative grain-size distribution of settled and resuspended sediments. Comparison of predictions with observations at an experimental site in the south of Boulogne-sur-Mer proved the utility of the 3D multiclass approach to account for significant remote advection of fine sediments.

In addition to tide, wind-generated surface gravity waves constitute occasionally a

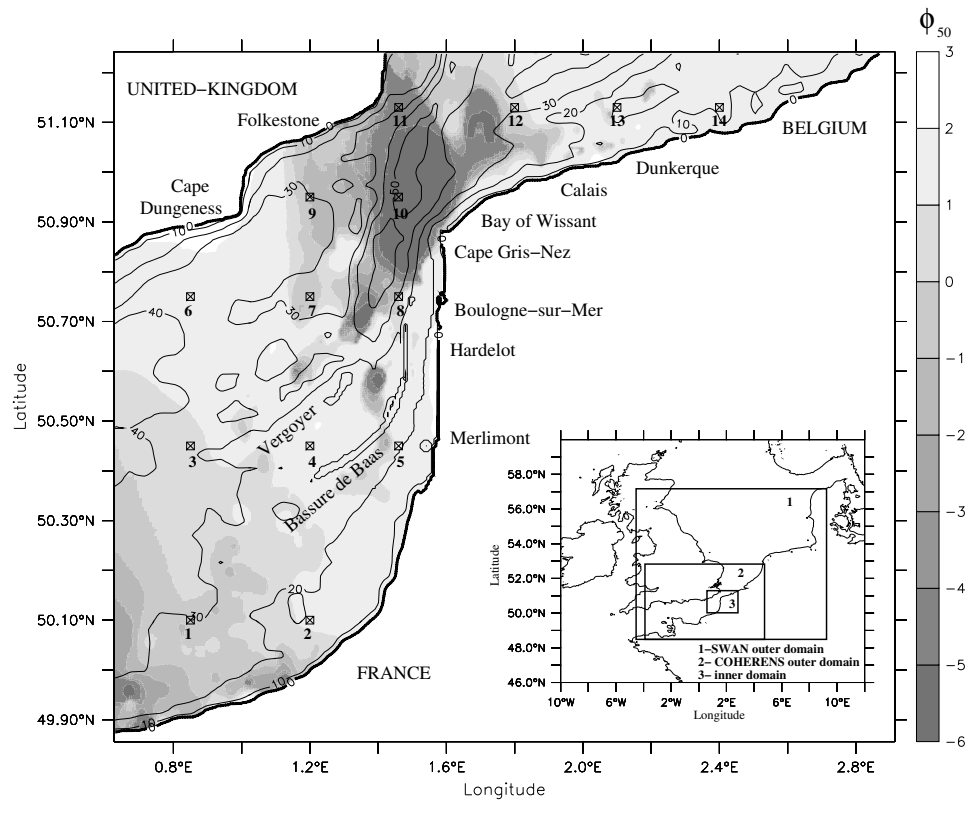

Figure 1: Studied zone and surficial sediment distribution portrayed with the median sieve diameter expressed in the Wentworth's grain-size scale $\phi_{50}=-\log _{2}\left(D_{50}\right)$ (with $D_{50}$ the median sieve diameter expressed in $\mathrm{mm}$ ) in the inner domain\#3. The bathymetry is indicated with black superimposed isolines. The right-bottom inset shows the computational domains\#1, \#2 and \#3. Squares numbered from \#1 to \#14 indicate the locations of the 14 points where modifications are the granulometric distribution are studied further in section 4.2 . 
second prominent hydrodynamic feature in the eastern English Channel. Very few studies have however been dedicated to the role played by waves on sediment dynamics. In the central Dover Strait, Mc Cave (1973), Eisma and Kalf (1979) and Van Alphen (1990) pointed out a zonation between high turbid coastal waters with near-free surface concentrations of $10-35 \mathrm{mgl}^{-1}$ and low turbid central waters with concentrations of $2-3 \mathrm{mg} \mathrm{l}^{-1}$. The seasonal variability of suspended sediment matter (SPM) through the Dover Strait potentially attributed to storm activity was revealed by the Fluxmanche project (e.g., Lafite et al., 2000). Grochowski and Collins (1994) and Velegrakis et al. (1999) have quantified the mobility of bed sediments with shear-stresses issued from a 2DH hydrodynamic model and uniform waves parameters. Gerritsen et al. (2000) have examined sensitivities of sediment resuspensions predicted by 2DH and 3D models using hindcast wave parameters and neglecting the interactions of the waves with the timevarying fields of water depths and currents.

The purpose of the present study is to numerically investigate the effects of a storm on resuspensions of heterogeneous bottom sediments in the eastern English Channel. The numerical investigation conducted by Guillou et al. (2009) under tide-dominated conditions is extended by computing waves and their interactions with the circulation and bottom sediment resuspensions. The application is dedicated to a storm in October 1998 with a focus on field measurements collected off Merlimont Beach in the south of Boulogne-sur-Mer.

The hydrodynamic modelling is based on the coupling of a wind-generated surface gravity-wave module (section 2.1.1) with a 3D circulation module (section 2.1.2). This coupling integrates (i) the influences of the free-surface elevation and the ambient current on the wave fields and (ii) the interaction between wave and current bottom boundary layers, namely the enhanced level of turbulence near the bottom and the increase of the total bottom shear stress. Transports in suspension of silts $\left(d_{1}=25 \mu \mathrm{m}\right)$, very fine sands $\left(d_{2}=75 \mu \mathrm{m}\right)$, fine sands $\left(d_{3}=150 \mu \mathrm{m}\right)$ and medium sands $\left(d_{4}=350 \mu \mathrm{m}\right)$ are computed (section 2.1.3). A pre-processing module determines the surficial sediment granulometric distributions and a series of related frictional parameters. The comparison with measurements (section 3) focuses on the waves parameters (height, bottom orbital velocity, period and direction) and the near-bottom current and total SSC. Mappings of the maximum wave and current skin bottom shear stress and the total SSC are produced in order to quantify the regional effects of the storm on bottom resuspensions (section 4.1). Finally, the modifications of the granulometric composition of suspended materials are investigated in 14 points evenly spaced over the study area (section 4.2).

\section{Materials and Methods}

\subsection{Model Description}

The numerical model couples the Simulating WAves Nearshore (SWAN) module (Booij et al., 1999), the 3D COupled Hydrodynamical-Ecological module for REgioNal and Shelf seas (COHERENS) (Luyten et al., 1999) and a 3D suspended sediment transport module adapting from COHERENS transport module (Guillou, 2007; Guillou et al., 2009). The principal model assumptions are placed on the two latter modules. They concern the flow which is assumed turbulent on a rough bed, the sedimentary particle assemblage which is made of $N_{p}$ cohesionless spherical quartz particules and the water-sediment 
mixture which is not affected by interactions between solid particles. These assumptions are identical to those adopted and described precisely in Guillou et al. (2009).

\subsubsection{Waves Module}

SWAN solves the time-dependent 2D spectral action balance equation (Booij et al., 1999). It accounts for depth shoaling, refraction and nonlinear transfer of wave energy through three-wave and four wave-interactions. The parametrizations adopted for sources and sinks are briefly detailed here. The wave growth by wind is computed with the exponential term of Komen et al. (1984). The processes of whitecapping are described with the pulse-based equation of Hasselmann (1974). The energy dissipation in random waves due to depth-induced breaking is quantified according to Battjes and Janssen (1978). The empirical model of Hasselmann et al. (1973) parametrizes the sink term of bottom friction. Finally, the effects of time-varying water depths and ambient currents are considered. As the waves propagate into a following current, the individual wave components lengthen and their amplitude are reduced. Whenever the current is in the opposite direction of the waves, the waves components are shortened and their amplitudes increase up to a point. The wave action balance equation is expressed in a spherical coordinate system. Further details about the mathematical expressions of sources and sinks are available in SWAN team (2009).

\subsubsection{Circulation Module}

COHERENS solves the continuity equation and the Reynolds-averaged momentum equations derived using the Boussinesq's $(1823,1903)$ approximations. The hydrostatic equilibrium is applied on the vertical. The horizontal eddy viscosity $\nu_{H}$ is parametrized following Smagorinsky (1963). The vertical eddy viscosity is expressed as $\nu_{T}=0.108 k^{2} / \varepsilon$ where $k$ is the turbulent kinetic energy and $\varepsilon$ is its dissipation rate. These turbulent moments are obtained by solving a pair of transport equations which are well-known as the $k-\varepsilon$ turbulence closure scheme (e.g., Launder and Spalding, 1974). The momentum and turbulent equations are subjected to bottom boundary conditions derived from the law of the wall. Surface boundary conditions integrate the effects of the wind following Geernaert et al. (1986). Finally, the main features of the interactions between wave and current bottom boundary layers are computed according to Grant and Madsen (1979), namely (i) the total maximum wave and current bottom shear stress $\tau_{b, c \omega}^{\max }$, (ii) the enhanced levels of the turbulence and the vertical eddy viscosity $\nu_{T}$ near the bottom and (iii) the increase of the apparent roughness $z_{0 c}$ felt by the current above the wave boundary layer. The set of equations is expressed in a spherical $-\sigma$ coordinate system. Further details about the circulation module are available in Luyten et al. (1999).

\subsubsection{Suspended Sediment Transport Module}

The instantaneous volumetric concentration $C_{i}$ of each individual class subscripted $i$, with $1 \leq i \leq N_{p}$, is interpreted as an arbitrary scalar quantity satisfying the transport equation

$$
\frac{\partial H C_{i}}{\partial t}+\nabla \cdot\left(H C_{i} \mathbf{u}\right)+\frac{\partial}{\partial \sigma}\left[\left(\tilde{w}-w_{s i}\right) C_{i}\right]=\frac{\partial}{\partial \sigma}\left(\frac{\lambda_{T}}{H} \frac{\partial C_{i}}{\partial \sigma}\right)+\nabla \cdot\left(H \lambda_{H} \nabla\left(C_{i}\right)\right)
$$

where $t$ denotes time, $\mathbf{u}$ is the horizontal velocity component, $H$ is the instantaneous total water depth, $\tilde{w}$ is the vertical velocity normal to $\sigma$-planes, $\boldsymbol{\nabla}$ is the horizontal gradient 
operator, $\lambda_{H}$ is the horizontal eddy diffusivity parametrized following Smagorinsky (1963) and $\lambda_{T}$ is the vertical eddy diffusivity expressed as $\lambda_{T}=0.177 k^{2} / \varepsilon$. Finally, $w_{s i}$ is the settling velocity of particle from size class $i$ given by the Soulsby's (1997) formulation.

A zero mass flux condition is imposed at the free-surface. The bottom boundary condition specifies the net mass flux through the bottom level of suspension:

$$
w_{s i} C_{i}+\frac{\lambda_{T}}{H} \frac{\partial C_{i}}{\partial \sigma}=D_{i}-E_{i}
$$

where $D_{i}$ is the deposition rate due to settling and $E_{i}$ is the upward turbulent entrainment rate.

The deposition rate is simply expressed as

$$
D_{i}=w_{s i} C_{i}^{b o t}
$$

where $C_{i}^{b o t}$ is the near-bed SSC (e.g., Lick, 1982; Lavelle et al., 1984; Chapalain and Thais, 2000).

The entrainment rate is specified following Van Rijn (1986), Celik and Rodi (1988, 1991), Chapalain and Thais (2000) and Harris and Wiberg (2001, 2002):

$$
E_{i}=w_{s i} C_{i}^{r e f}
$$

in which the maximum equilibrium near-bed reference $\operatorname{SSC} C_{i}^{\text {ref }}$ is given by the semiempirical expression of Smith and Lean (1977)

$$
C_{i}^{r e f}=f_{i} C_{b}\left(\frac{\gamma_{0} T_{s i}}{1+\gamma_{0} T_{s i}}\right)
$$

where $C_{b}=0.65$ is the total volume concentration of sediment in the settled bed (1porosity) and $f_{i}$ is the availability of sedimentary particles in size class $i$. The resuspension parameter $\gamma_{0}$ is taken equal to $\gamma_{0}=1.25 \times 10^{-3}$. This falls in the range $\left[10^{-5} ; 10^{-3}\right]$ obtained by compiling the values suggested by Dyer (1980), Wiberg and Smith (1983), Drake and Cacchione (1989) and Vincent and Green (1990) in continental shelf seas. $T_{s i}$ is the local normalized excess shear-stress between (i) $\tau_{b, c \omega}^{\max , s k i n}$ the module of the total maximum wave and current skin bottom shear stress and (ii) $\tau_{c r i}$ the critical value above which sediment particles of class $i$ are moved taking into account hiding-exposure effects on heterogeneous bottom sediments. Further details about the suspended sediment transport module are available in Guillou et al. (2009) and Guillou and Chapalain (2010).

\subsubsection{Numerical Methods}

SWAN time-dependent 2D spectral action balance equation is solved on a regular staggered grid, a constant directional resolution and an exponential frequency distribution with an implicit time discretization Euler technique. COHERENS hydrodynamic and SSC transport equations are solved on a regular staggered grid with numerical schemes for space and time discretizations issued from the standard version of the code (Luyten et al., 1999). The coupling between SWAN and COHERENS is realized performing computations of the waves and the circulation one after another. COHERENS is first 
launched neglecting the effects of the apparent roughness felt by the current over the wave boundary layer. Predicted fields of free surface elevations and depth-averaged currents are then introduced as input forcings in SWAN. Finally, waves output fields are provided to the wave and current interaction sub-module of COHERENS (section 2.1.2).

Furthermore, a fine resolution near-bed method is implemented to improve the computation of SSC and deposition rates at the water-sediment interface. It consists in (i) imposing analytical solutions based on the discontinuous eddy viscosity profile of Grant and Madsen (1979) and the law-of-the-wall in a nested 13-level sub-grid between the bottom and the first vertical COHERENS $\sigma$ grid point and (ii) solving SSC equations through the entire water column from the lower nested grid point to the upper grid point near the free surface. This approach avoids matching problems of the SSC vertical profile particularly tedious during deposition phases around slack waters. Further details on this numerical method are given in Guillou (2007).

\subsection{Model Setup}

SWAN is implemented on (i) a $500 \mathrm{~m}$ resolution inner domain\#3 extending from $0^{\circ} 626 \mathrm{E}$ to $2^{\circ} 914 \mathrm{E}$ and $49^{\circ} 856 \mathrm{~N}$ to $51^{\circ} 242 \mathrm{~N}$ embedded inside (ii) a $3 \mathrm{~km}$ resolution outer domain $\# 1$ extending in longitude from $4^{\circ} 600 \mathrm{~W}$ to $9^{\circ} 189 \mathrm{E}$ and in latitude from $48^{\circ} 408 \mathrm{~N}$ to $57^{\circ} 101 \mathrm{~N}$ (Fig. 1). SWAN runs on each computational domain with 30 exponentially spaced frequencies ranging from $0.0566 \mathrm{~Hz}$ to $1 \mathrm{~Hz}, 60$ evenly spaced directions $\left(6^{\circ}\right.$ resolution) and a time step of $5 \mathrm{mn}$ (e.g., Lin et al., 2002; Hu et al., 2003). The bottom friction coefficient is set to $C_{J O N}=0.038 \mathrm{~m}^{2} \mathrm{~s}^{-3}$ according to Bouws and Komen (1983). Wind velocity components at $10 \mathrm{~m}$ above the free surface are obtained from the database of the National Centers for Environmental Predictions (NCEP) (Kanamitsu et al., 2002). The outer model is driven by the hindcast wave parameters from the regional computations performed by Benoit and Lafon (2004) on the North-West European continental shelf. Data given every 30 min at 5 points along each open boundary are interpolated at all grid points and every time step. Finally, free-surface elevation and depth-averaged currents are extracted from COHERENS computations at 1.5 hours intervals in the English Channel.

COHERENS is set-up on (i) the domain\#3 embedded inside (ii) a $2 \mathrm{~km}$ outer domain\# 2 extending in longitude from $4^{\circ} 000 \mathrm{~W}$ to $4^{\circ} 707 \mathrm{E}$ and in latitude from $48^{\circ} 410 \mathrm{~N}$ to $52^{\circ} 837 \mathrm{~N}$ (Fig. 1). The outer model has 11 uniform vertical grid cells. The inner model has 14 uniform vertical grid cells completed with 13 above-mentioned (section 2.1.4) near-bed sublayer cells. The time steps for the external barotropic modes are 20 and 10 $\mathrm{s}$ for the outer and inner models, respectively. The time step for the internal baroclinic mode is $200 \mathrm{~s}$ for both models. The bottom roughness parameter is set to $z_{0}=0.0035 \mathrm{~m}$ in the outer domain (Luyten et al., 1999). In the inner domain, it is derived from the granulometric distribution of seabed sediments interpolated at all grid nodes from a series of bottom sediment samples collected from 1971 to 1976 in the framework of the RCP 378 Benthos de la Manche program (Cabioch et al., 1977). The granulometric distribution is discretized in 11 grain-size classes ranging from silts to pebbles with a supplemented virtual class of rock outcrops (Table 1). The map of the median sieve diameter computed (Fig. 1) reproduces fairly well the sediment pattern established by sedimentologists (e.g., Larsonneur et al., 1982). Further details about the application of the interpolation procedure to the inner domain \#3 are available in Guillou et al. (2009) and Guillou and Chapalain (2010). The outer computation is driven by the dominant 


\begin{tabular}{lll}
\hline $\begin{array}{l}\text { Type of sediment } \\
\text { fraction considered }\end{array}$ & $\begin{array}{l}\text { Standard sieves } \\
\text { diameters }\end{array}$ & $\begin{array}{l}\text { Nominal grain size } \\
\text { diameters }\end{array}$ \\
\hline Silts & $0-50 \mu \mathrm{m}$ & $d_{1}=25 \mu \mathrm{m}$ \\
Very fine sands & $50-100 \mu \mathrm{m}$ & $d_{2}=75 \mu \mathrm{m}$ \\
Fine sands & $100-200 \mu \mathrm{m}$ & $d_{3}=150 \mu \mathrm{m}$ \\
Medium sands & $200-500 \mu \mathrm{m}$ & $d_{4}=350 \mu \mathrm{m}$ \\
Coarse sands & $0.5-1 \mathrm{~mm}$ & $d_{5}=750 \mu \mathrm{m}$ \\
Very coarse sands & $1-2 \mathrm{~mm}$ & $d_{6}=1.5 \mathrm{~mm}$ \\
Gravels & $2-5 \mathrm{~mm}$ & $d_{7}=3.5 \mathrm{~mm}$ \\
& $0.5-1 \mathrm{~cm}$ & $d_{8}=7.5 \mathrm{~mm}$ \\
Pebbles & $1-2 \mathrm{~cm}$ & $d_{9}=1.5 \mathrm{~cm}$ \\
Rock outcrops & $2-5.5 \mathrm{~cm}$ & $d_{10}=3.75 \mathrm{~cm}$ \\
& $5.5-50 \mathrm{~cm}$ & $d_{11}=27.75 \mathrm{~cm}$ \\
\hline
\end{tabular}

Table 1: Grain-size diameters of each class considered.

tidal constituents extracted from a long-term run of COHERENS 2DH module on the North-West European continental shelf (José Ozer, Management Unit of the North Sea Mathematical Models, personal communication, 1999). The tidal signal predicted every 10 min at 15 points along each open boundary is interpolated at all grid points and every time step using a cubic spline algorithm. Wind data forcings are also considered. Finally, SWAN outputs provided at 1 hour intervals in the inner domain\#1 are interpolated at each time steps of COHERENS barotropic mode.

Suspended sediment transport is computed on the inner domain\#1 where the sediment distributions are introduced. Preliminary studies showed that the movement of bottom sediments was negligible for diameters over $500 \mu \mathrm{m}$. Computations are thus performed for the four grain size classes of silts $\left(d_{1}=25 \mu \mathrm{m}\right)$, very fine sands $\left(d_{2}=75 \mu \mathrm{m}\right)$, fine sands $\left(d_{3}=150 \mu \mathrm{m}\right)$ and medium sands $\left(d_{4}=350 \mu \mathrm{m}\right)$ (Table 2$)$.

\begin{tabular}{|c|c|c|}
\hline $\begin{array}{r}d_{i} \\
(\mu \mathrm{m}) \\
\end{array}$ & $\begin{array}{r}\tau_{c r i} \\
\left(\mathrm{~N} \mathrm{~m}^{-2}\right) \\
\end{array}$ & $\begin{array}{r}w_{s i} \\
\left(\mathrm{mms}^{-1}\right) \\
\end{array}$ \\
\hline 25 & 0.074 & 0.4 \\
\hline 75 & 0.129 & 3.2 \\
\hline 150 & 0.162 & 12 \\
\hline 350 & 0.216 & 45 \\
\hline
\end{tabular}

Table 2: Grain-size diameters, bottom critical shear stresses and settling velocities of each class considered for suspension.

\section{Comparison of Model Predictions With Point Measurements}

\subsection{Experiment Description}

Measurements here used were made at a site located off Merlimont Beach, at longitude $1^{\circ} 537 \mathrm{E}$ and latitude $50^{\circ} 450 \mathrm{~N}$ in mean water depth of $13.5 \mathrm{~m}$ (Fig. 1). An echo sounder survey showed that the bottom in this area was featureless and flat. Bed sediments were collected at the experimental site. The bottom sediment is sand with a median sieve diameter $D_{50}=256 \mu \mathrm{m}$ comprising $7 \%$ silt and very fine sand, $39 \%$ fine sand, $50 \%$ medium sand and $4 \%$ coarse and very coarse sand. The surrounding spatial distribution 
of bottom sediments presents a nearshore belt of bottom silty sand between Merlimont and Boulogne-sur-Mer (Fig. 1).

The instrumentation was deployed over the period 5-9 October 1998. The series of measurements was characterized by a spring tidal range of $9 \mathrm{~m}$. At the end of the experimental period, northerly storm wind and surface waves prevailed. The wind speed reaches $12 \mathrm{~m} \mathrm{~s}^{-1}$ and the significant wave height increases to $2.10 \mathrm{~m}$.

The instrumentation system is a heavily weighted benthic tripod equipped with an instrument package resolving the inner boundary layer every half hour at a rate of $4 \mathrm{~Hz}$ in 9-min records. It incorporates a Paroscientific pressure sensor located at $\mathrm{z}=2.17 \mathrm{~m}$ above the bottom and a vertical array of two Marsh-Mc Birney $3.8 \mathrm{~cm}$ diameter electromagnetic current meters and D\&A infra-red Optical Backscatterance Sensors (OBS-III) positioned at heights $\mathrm{z}=0.3$ and $0.6 \mathrm{~m}$ above the bottom. Data used here represent time series of burst averages. Further details about the instrumentation system and the data calibration and reduction procedure are available in Chapalain et al. (1999) and Chapalain and Thais (2000).

\subsection{Waves Parameters}

Predicted times series of the wave height $h_{m 0}$, the near-bottom orbital velocity $u_{b, r m s}$, the wave period and direction are compared with measurements at the Merlimont site (Fig. 2). The origin of the time series corresponds to 20:30 UT on 5 October 1998. The model reproduces fairly well the evolution of $h_{m 0}$ with a difference lower than $5 \%$ at the height of the storm. A slight underestimation (around $15 \%$ ) by the model of $u_{b, r m s}$ is at the same time obtained. At the beginning of the measurement period, the variations of the waves height due to the current are slightly underestimated, i.e. the reduction of their amplitudes into a following southerly ebb current and their increase in an opposite northerly flood current (section 2.1.1). The influence of the water depth on the bottom orbital velocity is better reproduced. Measurements and predictions are thus exhibiting a $40 \%$ increase of $u_{b, r m s}$ at low ebb tides when the total water depth is at its minimum. Finally, an overall good agreement is obtained for the wave period and direction.

\subsection{Near-Bottom Currents}

The current predominantly flows north and ebbs south almost parallel to the coastline (Fig. 3). Its temporal variation between successive ebb and flood peaks is fairly well reproduced by the model. The amplitude of the ebb current peak is however underestimated at 07:00 UT on 8 October 1998. A local northerly wind event observed at the semaphore of Boulogne-sur-Mer may explain the increase of the current amplitude at the experimental site. Nevertheless, such meteorological episode is not reproduced in the numerical wind NCEP data used to force the circulation model. Finally, a slight underestimation by $5-10 \%$ of the ebb current speed is noticed at the first vertical level in the beginning of the measurement period. This difference progressively diminishes as the current amplitude lessens due to the increase of the apparent roughness parameter $z_{0 c}$ during the storm. It even vanishes at 18:00 UT on 8 October 1998. The comparison of simulations with and without waves shows that the storm was reducing the current speed by $24 \%$ at $0.3 \mathrm{~m}$ above the bottom at the experimental site. 

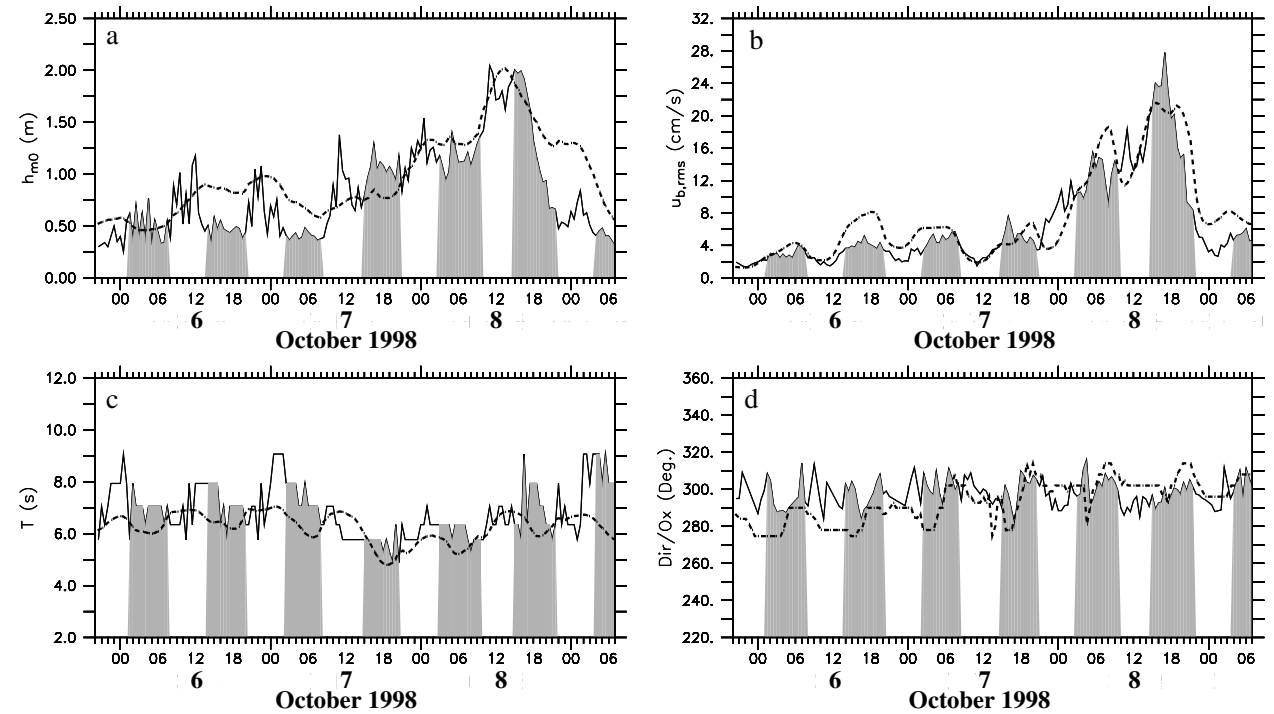

Figure 2: Measured (black line) and computed (dotted line) time series of (a) the significant wave height $h_{m 0}$, (b) the orbital velocity near the bottom $u_{b, r m s}$, (c) the wave period and (d) direction (clockwise from the north) at the Merlimont site in October 1998. Ebb period are indicated by surfaces in grey.
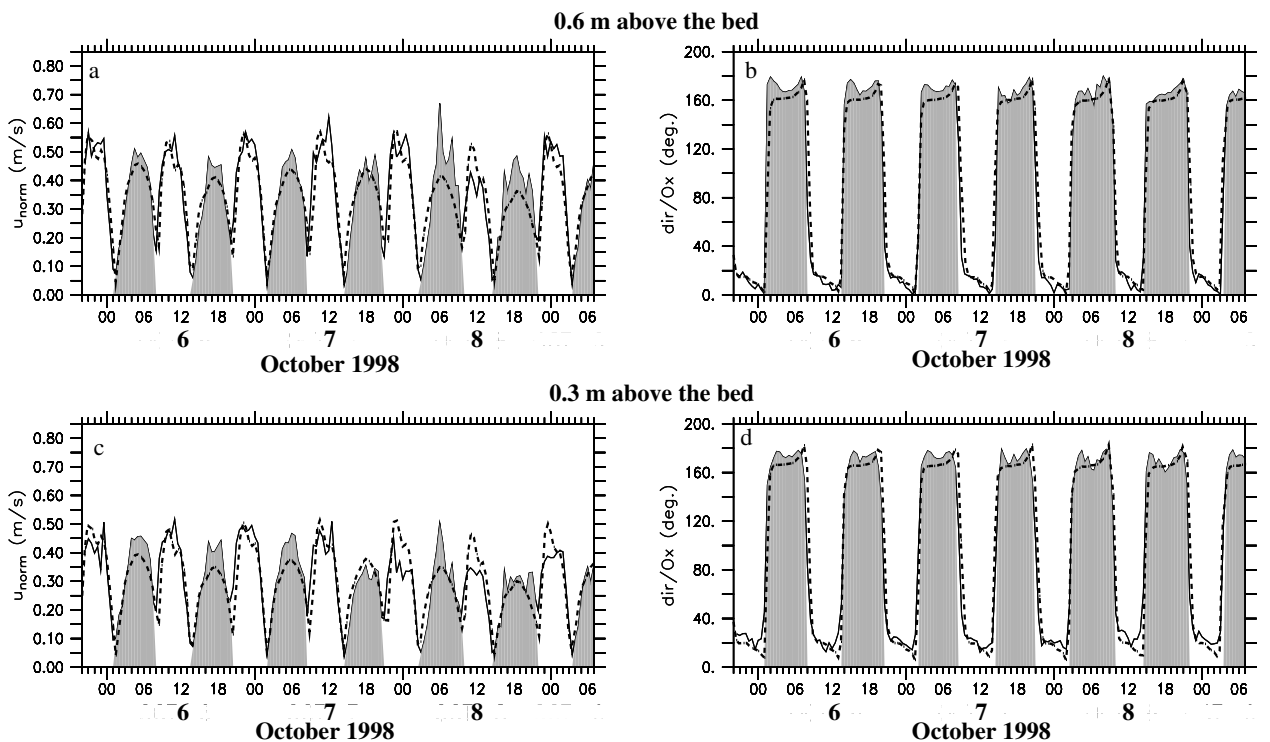

Figure 3: Measured (black line) and computed (dotted line) time series of the current speed and direction (anti-clockwise from the East) at 0.3 and $0.6 \mathrm{~m}$ above the bottom at the Merlimont site in October 1998. Ebb period are indicated by surfaces in grey. 


\subsection{Near-Bottom Total SSC}

The model reproduces (i) at the beginning of the measurement period the magnitude of the semidiurnal SSC peaks appearing at the end of the ebb and (ii) during the storm the increase by four of the total SSC from $100 \mathrm{mgl}^{-1}$ to $400 \mathrm{mgl}^{-1}$ (Fig. 4). Numerical results are however exhibiting flood SSC peaks unidentified on observations. Furthermore, the time series of the predicted total SSC is phase advance compared with the measurement. The phase lag decreases from three hours at the beginning of the measurement period to two hours during the storm. These differences may be explained by the greater sensitivity of OBS sensors to suspended silt than to suspended sand (e.g., Downing et al., 1981; Green et al., 1999). Indeed, the total SSC at the experimental site results from the contributions of the three grain size classes of silts $\left(d_{1}=25 \mu \mathrm{m}\right)$, very fine sands $\left(d_{2}=75 \mu \mathrm{m}\right)$ and fine sands $\left(d_{3}=150 \mu \mathrm{m}\right)$. At the beginning of the experimental campaign, the measured total SSC is thus consistent with the predicted SSC of the finest classes of silts and very fine sands three hours out of phase with the local shear stress. The lowest sensor response is obtained during flood SSC peaks dominated by the resuspensions of fine sands. During the storm, the total measured SSC is more sensitive to the contribution of the coarser class as the concentration of suspended fine sands exceeds $200 \mathrm{mg} \mathrm{l}^{-1}$. This is naturally reducing the phase lag between the predicted and measured total SSC.

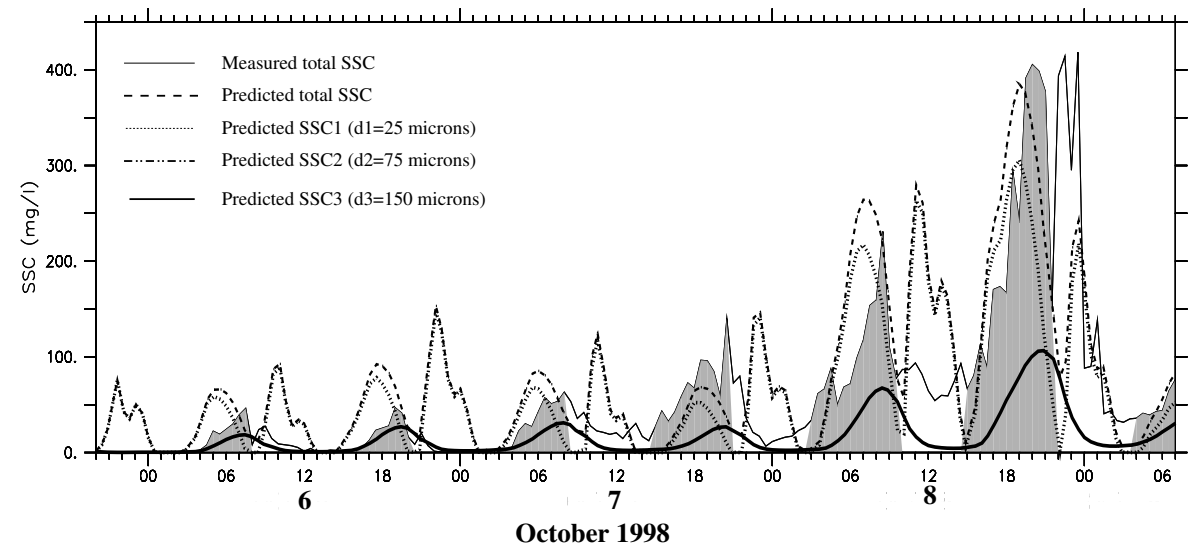

Figure 4: Time series of the measured and computed total SSC and the predicted SSC of silts and very fine sands $\left(d_{1}=25 \mu \mathrm{m}+d_{2}=75 \mu \mathrm{m}\right)$ and fine sands $\left(d_{3}=150 \mu \mathrm{m}\right)$ at $0.3 \mathrm{~m}$ above the bottom at the Merlimont site in October 1998. Ebb period are indicated by surfaces in grey.

\section{Discussion}

Guillou et al. (2009) have identified in tide-dominated conditions the contributions of each individual class to the total SSC at the experimental site. The suspended concentration of fine sands presents a quarter-diurnal variation in phase with the local shear stress. The contribution of the finest classes is associated with high resuspensions along the nearshore belt of bottom silty sand between Merlimont and Boulogne-sur-Mer and 
advection to the measurement point during ebb. The highest concentration of silts and very fine sands is thus found at the end of the ebb off Merlimont Beach. Such semidiurnal variability of SSC in semidiurnal tidal conditions has also been identified in the North Atlantic continental shelf by Weeks and Simpson (1991), Jago et al. (1994) and Aldridge (1996) confirming the close relationship with advection in the presence of horizontal concentration gradients. These processes are also exhibited for the extreme waves conditions of 8 October 1998. The southern part of the Dover Strait experiences however a significant increase of the resuspensions magnitude whereas this area is weakly exposed to the northerly incoming waves. The present investigation focuses on the regional effects of this storm by successively considering the increases of the total SSC near the bottom and the free surface and the changes in the granulometric composition of suspended materials.

\subsection{Maximum Total SSC}

Fig. 5 displays the predicted synoptic fields of the maximum wave and current skin bottom shear stress and the near-bottom total SSC on 8 October 1998. The highest levels of resuspensions are obtained in the exposed northern French coastline from Wissant to Dunkerque and the offshore bed features of the Flandres sandbanks. In this area, the near-bottom total SSC exceeds $2.5 \mathrm{gl}^{-1}$ in waters located approximately $2 \mathrm{~km}$ offshore. Whereas the skin bottom shear stress exceeds with a spatial average value of $10 \mathrm{~N} \mathrm{~m}^{-2}$ the threshold of motion of gravels of $7.5 \mathrm{~mm}\left(\tau_{c r 8}=6.5 \mathrm{~N} \mathrm{~m}^{-2}\right)$, the contribution of coarse materials to the near-bottom total SSC remain negligible. Indeed, under the extreme shear stress of $u_{*}=12 \mathrm{~cm} \mathrm{~s}^{-1}\left(\tau_{\text {skin }}=15 \mathrm{~N} \mathrm{~m}^{-2}\right)$ at the height of the storm, the criterion for the threshold of suspension $u_{*}>w_{s}$ (e.g., Soulsby, 1997) is only achieved for the fifth grain-size class of coarse sand $\left(d_{5}=750 \mu \mathrm{m}\right)$ with a settling velocity of $w_{s}=9.3 \mathrm{~cm} \mathrm{~s}^{-1}$. This analysis confirms that the contribution to the total SSC is limited to the first four grain-size classes during the storm. Lower levels of resuspensions are identified in the southern part of the Dover Strait where the near-bottom total SSC remains below $900 \mathrm{mgl}^{-1}$. This region presents similar spots as those identified under tide-dominated conditions by Guillou et al. (2009) seaward the English coast, off Dungeness and Folkestone with an southward excrescence, and the French coast, in the south of Boulogne-sur-Mer, off the bay of Somme and Dieppe. Waves are however exhibiting resuspensions in shallow water revealing bed features of the Vergoyer and Bassure de Baas sandbanks. This effect is particularly noticeable on the top of the Bassure de Baas where the near-bottom total SSC is reaching $2 \mathrm{gl}^{-1}$ in a $500 \mathrm{~m}$ wide strip following the shape of the feature (Fig. 5-b). In the central part of the Strait, waves modify the zonation between central and coastal waters (Mc Cave, 1973; Eisma and Kalf, 1979; Van Alphen, 1990) exhibiting three main areas of resuspensions: (i) the English coastline associated with weak SSC below $300 \mathrm{mg} \mathrm{l}^{-1}$, (ii) the transitional zone of gravel and pebbles deposits where no resuspension occurs and (iii) the French coastal zone showing the highest nearbottom SSC. Waves may thus have an impact in the variable and sometimes high SSC observed in the French coastal zone (e.g., Velegrakis et al., 1999)

The effects of the storm are further quantified through the increase of the maximum wave and current skin bottom shear stress and the near-bottom total SSC for simulations with and without waves (Fig. 6). The maximum skin bottom shear stress increases by six in nearshore areas and on the top of the Vergoyer and the Bassure de Baas sandbanks. This falls in the range of values [3;30] computed by Kemp and Simons (1984) for similar waves and current conditions. The storm increases the maximum near-bottom total SSC 

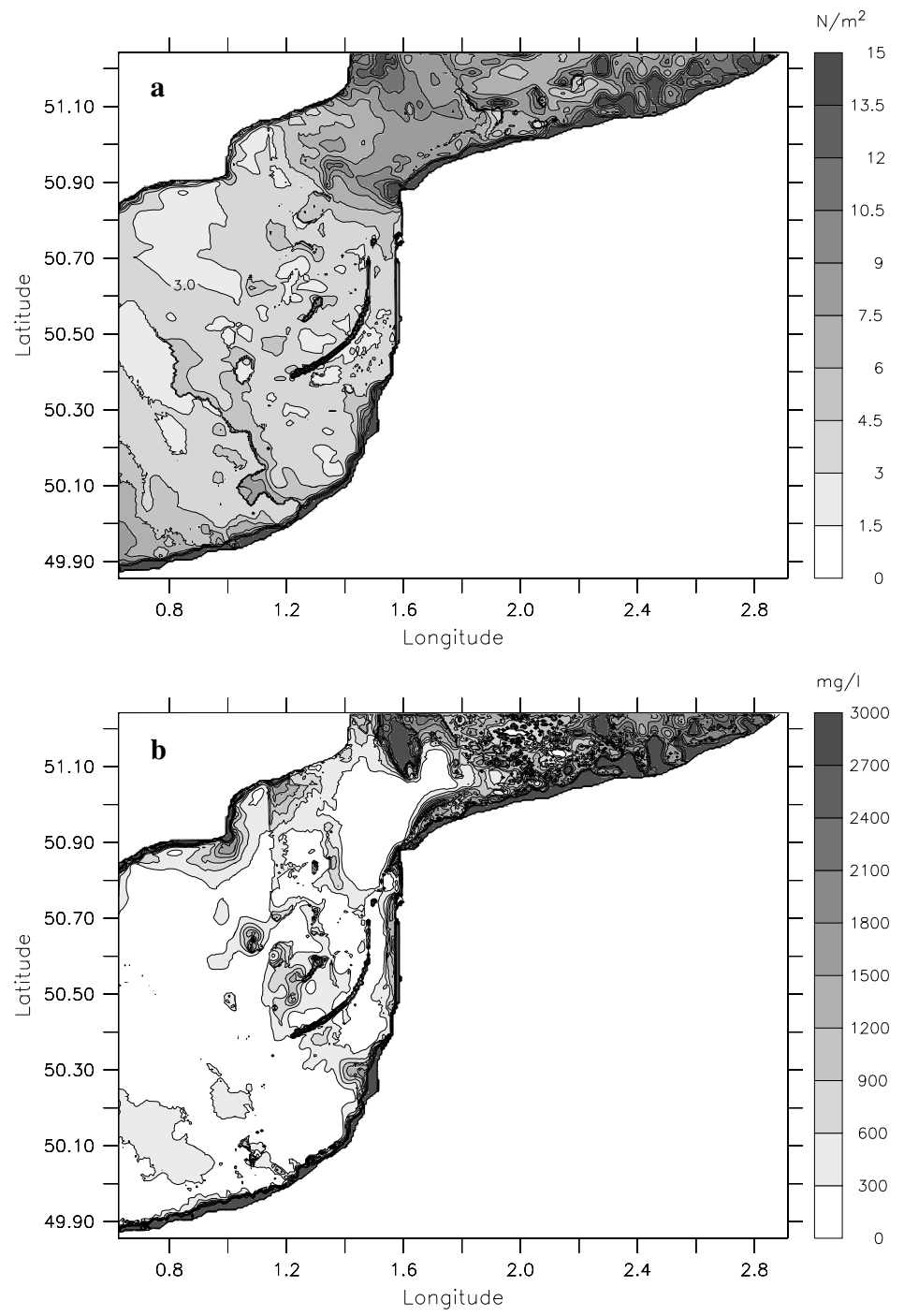

Figure 5: Predicted maximum (a) wave and current skin bottom shear stress and (b) total SSC at 30 cm above the bottom on 8 October 1998.

to up to 40 times in the northern exposed areas. Comparable increases were reported from the field study conducted off Maplin Sands (UK) by Owen and Thorn (1978). Numerical simulations by Gerritsen et al. (2000) exhibited also increases by 10-20 of the depth-averaged total SSC in the German Bight. The growth of the near-bottom total SSC is limited to five in deep waters of the southern Dover Strait. The increases of the resuspensions in the eastern English channel are associated with local westerly incoming waves and the great disponibility of medium sands mainly settled in suspension by waves. 

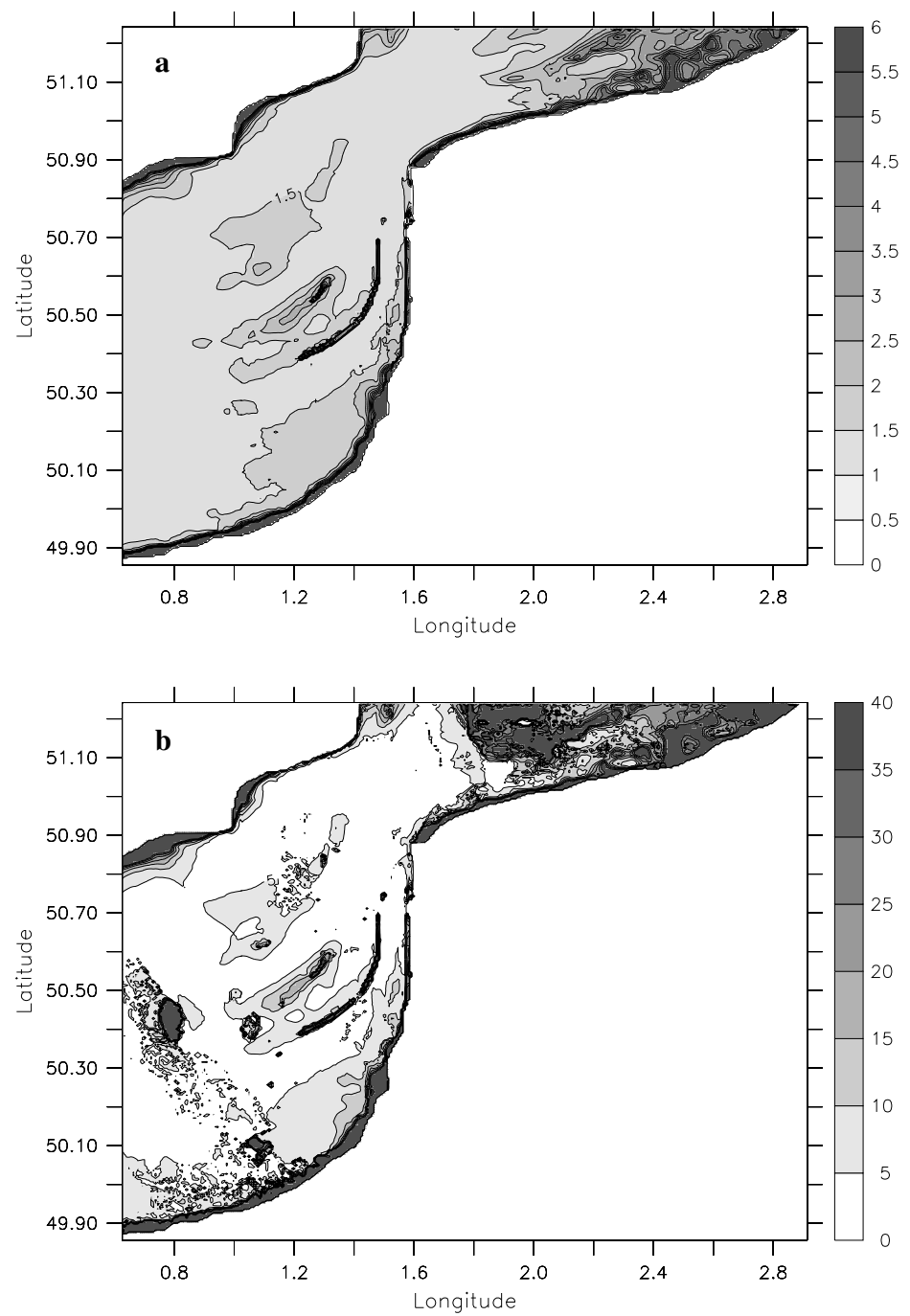

Figure 6: Increases of the maximum (a) wave and current skin bottom shear stress $\left(u_{* c \omega}^{\max } / u_{* c}^{\max }\right)$ and (b) the total SSC at $30 \mathrm{~cm}$ above the bottom $\left(C_{\mathrm{bottom} \text {, current+waves }}^{\max } / C_{\mathrm{bottom}}^{\mathrm{max}}\right.$, current $)$ due to the storm of 8 October 1998 .

Finally, the effect of the storm on the near-free surface total SSC is analysed (Fig. 7) as it is a major factor in determining the light levels for the biological activity. The predicted synoptic field exhibits nearshore fine sediment supplies with a magnitude of the near-free surface total SSC reduced by 10-15 in comparison with the level of nearbottom resuspensions. The topographical features of the Vergoyer and the Bassure de Baas sandbanks are still visible. 


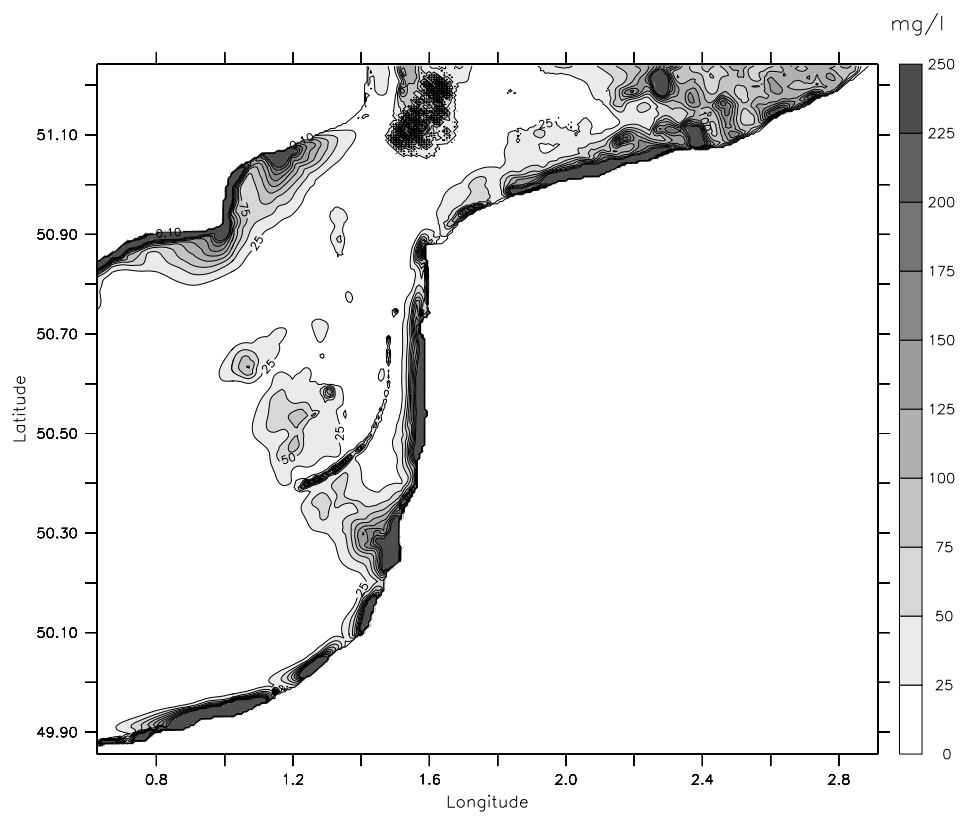

Figure 7: Predicted maximum total SSC at $30 \mathrm{~cm}$ below the free surface on 8 October 1998.

\subsection{Granulometric Composition of Suspended Materials}

The effects of the storm on the grain-size composition of suspended materials are investigated in 14 points evenly spaced in the inner computational domain (Fig. 1). These points are located in water depths exceeding $15 \mathrm{~m}$ so that the proportions of the finest classes of silts and very fine sands $(\mathrm{C} 1+\mathrm{C} 2)$ in bed sediments are negligible (Table $3)$. The type of bottom sediments considered varies from gravels and pebbles deposits in the central part of the Strait (points\#7, \#8, \#10, \#11 and \#12) to coarse sands with a low (points $\# 1, \# 2, \# 3, \# 6, \# 13$ and \#14) and medium (points \#4, \#5 and \#9) proportions of fine sands at the western and north-eastern boundaries.

When waves are neglected, medium sands are settled in suspension in the southwestern limit of the Dover Strait (point\#1) and the central area where the current bottom shear stresses are the most significant. Elsewhere, suspended sediments consist mainly of fine sands. This is consistent with investigations conducted by Guillou and Chapalain (2010) on suspended load induced by the dominant $\mathrm{M}_{2}$ tide in the English Channel. Proportions of silts and very fine sands between $3-7 \%$ are however appearing at some locations (points\#4, \#5, \#7 and \#9) whereas their local disponibilities are negligible (Table 3). This reveals the remote advection of close silty sands supplies located on both part of Dungeness foreland (point\#9), on the top of Vergoyer and the Bassure de Baas sandbanks (points\#5 and \#7) and in the south of Boulogne-sur-Mer (point\#9 and the experimental site off Merlimont).

The storm conditions slightly affect the grain-size distribution of suspended materials in the south-eastern less exposed area of the Dover Strait (points\#2 to \#6). The contributions of the three first grain-size classes at the Merlimont site (section 3.4) confirm 
this result. Indeed, the ratio between the SSC of the finest classes $\left(d_{1}+d_{2}\right)$ and fine sands $\left(d_{3}\right)$ remains nearly the same during the measurement period (Fig. 4). An exposition to local westerly incoming waves is however fostering the resuspensions of medium sands at point\#1. In the northern exposed area, the contribution of medium sands prevails over the contribution of finer classes increasing the median diameter of near-bottom suspended materials. This effect is particularly visible on the Flandres sandbanks (points\#13 and \#14) where the contribution of medium sands increases to up to $60 \%$ when waves are taken into account. The storm has naturally no impact over the central gravel and pebbles deposits (point\#10) but increases the contribution of fine sands towards medium sands in the vicinity of fine sand supplies (points\#8 and \#9).

\begin{tabular}{|c|c|c|c|c|c|c|c|c|c|c|c|c|}
\hline \multirow{3}{*}{ Areas } & \multirow{3}{*}{ Point } & \multicolumn{2}{|c|}{ Coordinates } & \multirow{2}{*}{\multicolumn{3}{|c|}{$\begin{array}{c}\text { Proportions of } \\
\text { bed sediment (in \%) }\end{array}$}} & \multirow{2}{*}{\multicolumn{3}{|c|}{$\begin{array}{l}\text { Composition of maximum near } \\
\text { without waves }\end{array}$}} & \multirow{2}{*}{\multicolumn{3}{|c|}{ bottom total SSC (in \%) }} \\
\hline & & Long. & Lat. & & & & & & & & & \\
\hline & & & & $C_{1}+C_{2}$ & $C_{3}$ & $C_{4}$ & $C_{1}+C_{2}$ & $C_{3}$ & $C_{4}$ & $C_{1}+C_{2}$ & $C_{3}$ & $C_{4}$ \\
\hline & 1 & 0.85 & 50.10 & 0.0 & 4.0 & 19.0 & 0.0 & 89.0 & 11.0 & 0.0 & 71.3 & 28.7 \\
\hline & 2 & 1.20 & 50.10 & 0.0 & 1.0 & 63.0 & 0.1 & 99.9 & 0.0 & 0.5 & 99.5 & 0.0 \\
\hline Eastern & 3 & 0.85 & 50.45 & 0.0 & 0.0 & 37.0 & 0.9 & 99.1 & 0.0 & 1.1 & 98.9 & 0.0 \\
\hline \multirow[t]{3}{*}{ English Channel } & 4 & 1.20 & 50.45 & 0.0 & 13.0 & 67.0 & 3.3 & 96.7 & 0.0 & 5.4 & 94.6 & 0.0 \\
\hline & 5 & 1.46 & 50.45 & 0.0 & 5.0 & 48.0 & 7.5 & 92.5 & 0.0 & 9.9 & 90.0 & 0.0 \\
\hline & 6 & 0.85 & 50.75 & 0.0 & 3.0 & 77.0 & 0.4 & 99.6 & 0.0 & 0.1 & 99.9 & 0.0 \\
\hline & 7 & 1.20 & 50.75 & 0.0 & 1.0 & 15.0 & 3.5 & 75.0 & 21.5 & 1.0 & 45.1 & 53.9 \\
\hline Dover & 8 & 1.46 & 50.75 & 0.0 & 2.0 & 34.0 & 0.1 & 9.2 & 90.7 & 0.0 & 19.6 & 80.4 \\
\hline \multirow[t]{2}{*}{ Strait } & 9 & 1.20 & 50.95 & 0.0 & 4.0 & 28.0 & 2.4 & 29.4 & 68.2 & 1.1 & 57.8 & 41.1 \\
\hline & 10 & 1.46 & 50.95 & 0.0 & 0.0 & 1.0 & 1.1 & 28.2 & 70.7 & 0.6 & 22.0 & 77.4 \\
\hline \multirow{4}{*}{$\begin{array}{l}\text { Southern } \\
\text { North Sea }\end{array}$} & 11 & 1.46 & 51.13 & 0.0 & 1.0 & 12.0 & 0.1 & 47.5 & 52.4 & 0.1 & 27.4 & 74.5 \\
\hline & 12 & 1.80 & 51.13 & 0.0 & 0.0 & 29.0 & 0.0 & 31.5 & 68.5 & 0 & 18.8 & 81.2 \\
\hline & 13 & 2.10 & 51.13 & 0.0 & 3.0 & 68.0 & 0.5 & 99.4 & 0.1 & 0.1 & 16.9 & 83.0 \\
\hline & 14 & 2.40 & 51.13 & 0.0 & 12.0 & 63.0 & 0.0 & 100.0 & 0.0 & 0.0 & 37.0 & 63.0 \\
\hline
\end{tabular}

Table 3: Proportions of silty to very fine sands $\left(C_{1}+C_{2}\right)$, fine sands $\left(C_{3}\right)$ and medium sands $\left(C_{4}\right)$ in maximum near-bottom total SSC on 8 October 1998 at the 14 points covering the Dover Straits (Fig. $1)$.

\section{Conclusions}

A 3D heterogeneous sediment transport module coupled with COHERENS circulation and SWAN wave propagation modules has been used to investigate the effects of the storm of 8 October 1998 on resuspensions of bottom sediments in the eastern English Channel. Numerical predictions have been compared with measurements off Merlimont Beach in the south of Boulogne-sur-Mer. The main outcomes of the present study are the following.

(1) Predicted time series of waves settings features and near-bottom currents show a fairly good agreement with measurements at the experimental site. These comparisons highlight the local effects of (i) the current on the significant wave height and (ii) the free surface elevation on the near-bottom orbital velocity. Furthermore, it quantifies the attenuation of the current speed induced by the increase of the apparent roughness parameter at the height of the storm.

(2) The model reproduces the increase by four of the near-bottom total SSC observed at the Merlimont site. Whereas the OBS signal represents the silts fraction of suspended sediments well-above the bottom (Green et al., 2004), the comparison of numerical results with measurements shows that OBS sensors may also be greatly sensitive to the suspended finest grain-size fraction near the bottom.

(3) Mappings of the increases of the maximum skin bottom shear stress and the nearbottom total SSC at the height of the storm are produced. The storm hardly 
modifies the spatial repartition of the resuspension spots identified under tidedominated conditions by Guillou et al. (2009) in the southern part of the Dover Strait. The major effect is an increase of the near-bottom total SSC by a factor in the range $[24 ; 40]$ in the exposed features of the Flandres sandbanks. Waves are however exhibited offshore bed features of the Bassure de Baas and Vergoyer sandbanks with clearly identified bathymetric signatures on resuspensions near the bottom and the free surface. The zonation between coastal and central waters of the Strait is also influenced by the storm waves with high level of resuspension in the French coastal area.

(4) Resuspensions during the storm are limited to the contribution of the four grainsize classes of silts $\left(d_{1}=25 \mu \mathrm{m}\right)$, very fine sands $\left(d_{2}=75 \mu \mathrm{m}\right)$, fine sands $\left(d_{3}=\right.$ $150 \mu \mathrm{m})$ and medium sands $\left(d_{4}=350 \mu \mathrm{m}\right)$. The movement of medium sands is initiated during the storm. The granulometric composition of suspended materials is thus mainly modified (i) at the south-western entrance of the computational domain where the proportion of medium sands in the bottom is the most significant and (ii) in the exposed southern North Sea. In the eastern English Channel and the surrounding of the experimental site, slight modifications are however noticed. The near-bottom resuspensions remain dominated by the contributions of fine sands with remote advections of silts.

The present study is restricted to short modelling period limited to spring-neap tides in conjunction with storm waves events. A prospective will consist in simulating on annual periods the resuspension and transport of sediment accounting for real meteorological forcings of wind and surface gravity waves as well as inputs of fluxes of fresh waters and fines sediments through the open maritime boundaries, the Seine and the Thames rivers. These developments are currently in progress for an extended comparison of model predictions with ocean color satellite images of the mineral part of the SPM concentration (e.g.,, SPOT, SeaWiFS, Modis, Meris).

\section{Acknowledgements}

The authors are particularly grateful to Dr. Louis Cabioch for giving us access to the "RCP 378 Benthos de la Manche" data, to Dr. José Ozer (Management Unit of the North Sea Mathematical Models, Belgium) for providing us with tidal harmonic constituents issued from a long term run of COHERENS at the scale of the NorthWest European continental shelf and to Michel Benoit (Electricité De France - Laboratoire National d'Hydraulique et d'Electricité, France) for supplying us with wave settings features conditions at the open boundary of SWAN computational domains. Simulations were performed on computer facilities CAPARMOR (CAlcul PARallèle Mutualisé pour l'Océanographie et la Recherche). The present paper is a contribution to the CETMEF-IUEM joint research program MEMPHYS (MEsure Et Modélisation des Processus HYdrodynamiques et Sédimentaires dans les écosytèmes côtiers).

\section{References}

Aldridge, J., 1996. Optimal fitting of a model to observations of sediment concentration in the Irish sea. Estuarine and Coastal Modelling, Proceedings of the Fourth International Conference, San Diego USA, 417-428. 
Battjes, J., Janssen, J., 1978. Energy loss and set-up due to breaking of random waves. Proceedings of 16th International Conference of Coastal Engineering, Hambourg, 569-587.

Beck, C., Clabaut, P., Dewez, S., Vicaire, O., Chamley, H., Augris, C., Hoslin, R., Caillot, A., 1991. Sand bodies and sand transport paths at the English Channel-North Sea border: morphology, hydrodynamics and radioactive tracing. Oceanologica Acta, Proceedings of the International Colloquium on the environment of epicontinental seas, Lille, vol. sp. n11, 111-121.

Benoit, M., Lafon, F., 2004. A nearshore wave atlas along the coasts of France based on the numeric modelling of wave climate over 25 years. Coastal Engineering, 714-726.

Booij, N. R. C., Ris, R. C., Holthuijsen, L. H., 1999. A third generation wave model for coastal regions, part i, model description and validation. Journal of Geophysical Research 104 (C4), 7649-7666.

Boussinesq, J., 1823. Essai sur la théorie des eaux courantes. Mémoire présenté par divers savants à l'Académie des Sciences de Paris. Vol. 23. Paris, 380-398.

Boussinesq, J., 1903. Théorie analytique de la chaleur, mise en harmonie avec la thermodynamique et avec la théorie mécanique de la lumière. Gauthiers-Villars, Paris.

Bouws, E., Komen, G., 1983. On the balance between growth and dissipation in an extreme, depthlimited wind-sea in the southern North Sea. Journal of Physical Oceanography 13, 1653-1658.

Cabioch, L., Gentil, F., Glacon, R., Retière, C., 1977. Le macrobenthos des fonds meubles de la Manche : distribution générale et écologie, in Biology of Benthic Organims, edited by B.F. Keegan, P.O. Ceidigh, and P.J. Caston, Pergamon, Oxford, U.K, 115-128

Celik, I., Rodi, W., 1988. Modelling suspended sediment transport in non-equilibrium situations. Journal of Hydraulic Engineering 10 (114), 1157-1119.

Celik, I., Rodi, W., 1991. Suspended sediment-transport capacity for open channel flow. Journal of Hydraulic Engineering 2 (117), 191-204.

Chapalain, G., Thais, L., 2000. Tide, turbulence and suspended sediment modelling in the eastern English Channel. Coastal Engineering 41, 295-316.

Chapalain, G., Thais, L., Smaoui, H., 1999. Modeling of a tidal bottom boundary layer with suspended sediment. Hydrobiologia 414, 1-12.

Downing, J. P., Sternberg, R. W., Lister, C. R. B., 1981. New instrumentation for the investigation of sediment suspension processes in the shallow marine environment. Marine Geology, 42, 19-34.

Drake, D. E., Cacchione, D. A., 1989. Estimates of the suspended sediment reference concentration $\left(c_{a}\right)$ and resuspension coefficient $\left(\gamma_{0}\right)$ from near-bed observations on the California shelf. Continental Shelf Research 9, 51-64.

Dyer, K., 1980. Current velocity profiles over rippled bed and the threshold of movement of sand. Estuarine Coastal Marine Science 10, 181-189.

Eisma, D., Kalf, J., 1979. Distribution and particle size of suspended matter in the Southern Bight of the North Sea and the eastern Channel. Netherlands Journal of Sea Research 13 (2), 298-324.

Geernaert, G., Katsaros, K., Richter, K., 1986. Variation of the drag coefficient and its dependence on sea state. Journal of Geophysical Research 91, 7667-7679.

Gerritsen, H., Vos, R., der Kaaij, T. V., Lane, A., Boon, J., 2000. Suspended sediment modelling in a shelf sea (North Sea). Coastal Engineering 41, 317-352.

Grant, W. D., Madsen, O. S., 1979. Combined wave and current interaction with a rough bottom. Journal of Geophysical Research 84 (C4), 1797-1808.

Green, M. O., Dolphin, T. J., Swales, A., Vincent, C.E., 1999. Transport of mixed-size sediments in a tidal channel. Specialty Conference, Coastal Sediments'99, A.S.C.E., New York, 644-658.

Green, M. O., Vincent, C. E., Trembanis, A. C., 2004. Suspension of coarse and fine sand on a wavedominated shoreface, with implications for the development of rippled scour depressions. Continental Shelf Research 24, 317-335.

Grochowski, N., Collins, M., 1994. Wave activity on the sea-bed of the English Channel. J. mar. bio. Ass. U.K. 74, 739-742.

Grochowski, N. T. L., Collins, M. B., Boxall, S. R., Salomon, J. C., 1993a. Sediment transport predictions for the English Channel, using numerical models. Journal of the Geological Society 150, 683-695.

Grochowski, N. T. L., Collins, M. B., Boxall, S. R., Salomon, J. C., Breton, M., Lafite, R., 1993 b. Sediment transport pathways in the eastern Channel. Oceanologica Acta 16 (5-6), 531-537.

Guillou, N., 2007. Rôles de l'hétérogénéité des sédiments de fond et des interactions houle-courant sur l'hydrodynamique et la dynamique sédimentaire en zone subtidale - applications en Manche Orientale et à la pointe de la Bretagne. Ph.D. thesis, Université de Bretagne Occidentale. 469 pp. URL http://tel.archives-ouvertes.fr/tel-00376679/en/

Guillou, N., Chapalain, G., 2010. Numerical simulation of tide-induced transport of heterogeneous sediments in the English Channel. Continental Shelf Research 30, 806-819. 
Guillou, N., Chapalain, G., Thais, L., 2009. Three dimensional modelling of tide-induced suspended transport of seabed multicomponent sediments in the eastern English Channel. Journal of Geophysical research (114), C07025, 10.1029/2008JC004791.

Harris, C., Wiberg, P., 2001. A two-dimensional, time-dependent model of suspended sediment transport and bed reworking for continental shelves. Computers and Geosciences 27, 675-690.

Harris, C., Wiberg, P., 2002. Across-shelf sediment transport: Interactions between suspended sediment and bed sediment. Journal of Geophysical Research C1 (107), 10.1029/2000JC000634.

Hasselmann, K., 1974. On the spectral dissipation of ocean waves due to whitecapping. Boundary Layer Meteorology 1-2 (6), 107-127.

Hasselmann, K., Barnett, T. P., Bouws, E., Carlson, H., Cartwright, D. E., Enke, K., Ewing, J. A., Gienapp, H., Hasselmann, D. E., Kruseman, P., Meerburg, A., Muller, P., Olbers, D. J., Richter, K., Sell, W., Walden, H., 1973. Measurements of wind-wave growth and swell decay during the Joint North Sea Wave Project (JONSWAP). Dtsch. Hydrogr. Z. Suppl., A 8(12), 95 pp.

$\mathrm{Hu}$, K., Ding, P., Zhu, S., Kong, Y., 2003. Numerical simulation of typhoon waves around the waters of the Yangtze estuary - a case study of typhoon rusa and typhoon sinlaku. Proceedings of the International Conference on Estuaries and Coasts, Hangzhou, China, 929-936.

Jago, C., Bales, A., Green, M., Jones, S., Howard, M., McCave, I., Millward, G., Morris, A., Rowden, A., Williams, J., 1994. Resuspension processes and Seston dynamics, Southern North Sea. In: et al., H. C. (Ed.), Understanding the North Sea Systems. Chapman and Hall, London, 97-114.

Kanamitsu, M., Ebisuzaki, W., Woollen, J., Yang, S., Hnilo, J., Fiorino, M., Potter, G.L., 2002. NCEPDOE AMIP-II reanalysis (R-2). Bulletin of the American Meteorological Society, 83, 1631-1643.

Kemp, P., Simons, R., 1984. Sediment transport due to waves and currents. Proceedings of the IUTAM Symposium: Seabed Mechanics, 197-206.

Komen, G. J., Hasselman, S., Hasselman, K., 1984. On the existence of a fully developped wind-sea spectrum. Journal of Physical Oceanography 14, 1271-1285.

Lafite, R., Shimwell, S., Grochowski, N., Dupont, J.P., Nash, L., Salomon, J.C., Cabioch, L., Collins, M., Gao, S., 2000. Suspended particulate matter fluxes through the Straits of Dover, English Channel: observations and modelling. Oceanologica Acta, 23, 6, 687-699.

Larsonneur, C., Bouysse, P., Auffret, J.P., 1982. The superficial sediments of the English Channel and its western approaches. Sedimentology 29, 851-864.

Launder, B. E., Spalding, D. B., 1974. The numerical computation of turbulent flows. Computer Methods in Applied Mechanics and Engineering 3, 269-289.

Lavelle, J. W., Mofjeld, H. O., Baker, E. T., 1984. An in situ erosion rate for fine-grained marine sediment. Journal of Geophysical Research 89, 6543-6552.

Lick, W., 1982. Entrainment, deposition, and transport of fine-grained sediments in lakes. Hydrobiologia 91, 31-40

Lin, W., Sanford, L. P., Suttles, S. E., 2002. Wave measurement and modeling in Chesapeake bay. Continental Shelf Research 22, 2673-2686.

Luyten, P. J., Jones, J. E., Proctor, R., Tabor, A., Tett, P., Wild-Aden, K., 1999. COHERENS: A COupled Hydrodynamics-Ecological model for REgioNals and Shelf seas - Part III Model Description (Available on CD-ROM via http://www.mumm.ac.be/coherens). Management Unit of the North Sea Mathematical Models, Belgium, $200 \mathrm{pp}$

SWAN team, 2009. SWAN Cycle III Version 40.72 AB - Scientific and Technical Documentation. Tech. rep., Delft University of Technology, $107 \mathrm{pp}$.

Mc Cave, I. N., 1973. Mud in the North Sea. North Sea Science, MIT Press, 75-100.

Owen, M., Thorn, M., 1978. Effect of waves on sand transport by currents. Proceedings of the 16th Conference of Coastal Engineering. Hamburg, 1675-1687.

Smagorinsky, J., 1963. General circulation experiments with the primitive equations, i, the basic experiments. Monthly Weather Review 91, 99-164.

Smith, J. D., Lean, S. R. M., 1977. Spatially averaged flow over a wavy surface. Journal of Geophysical Research 12 (82), 1735-1746.

Soulsby, R., 1997. Dynamics of marine sands. H. R. Wallingford, 249 pp.

Souza, A. J., Holt, J. T., Proctor, R., 2007. Modelling SPM on the NW European shelf seas. Coastal Shelf Sediment Transport, 274, 147-158.

Van Alphen, J., 1990. A mud balance for Belgian-Dutch coastal waters between 1969 and 1986 . Neth. J. Sea. Res. 25 (1-2), 19-30.

Van Rijn, L. C., 1986. Mathematical modelling of suspended sediment in non-uniform flows. Journal of Hydraulic Engineering 6 (112), 433-455.

Velegrakis, A. F., Michel, D., Collins, M. B., Lafite, R., Oikonomou, E. K., Dupont, J. P., Huault, M. F., 
Lecouturier, M., Salomon, J. C., Bishop, C., 1999. Sources, sinks and resuspension of suspended particulate matter in the eastern English Channel. Continental Shelf Research 19, 1933-1957.

Vincent, C. E., Green, O. M., 1990. Field measurements of the suspended sand concentration profiles and fluxes, and of the resuspension coefficient $\gamma_{0}$ over a rippled bed. Journal of Geophysical Research $95,15,591-15,601$.

Weeks, A., Simpson, J. H., 1991. The measurements of suspended particulate concentrations from remotely sensed data. Int. J. Remote Sensing 12, 725-737.

Wiberg, P. L., Smith, J. D., 1983. A comparison of field data and theoritical models for wave-current interactions at the bed of the continental shelf. Continental Shelf Research 2, 147-162. 